\title{
Cyclophosphamide-induced symptomatic hyponatremia, a rare but severe side effect: a case report
}

This article was published in the following Dove Press journal:

OncoTargets and Therapy

30 September 2014

Number of times this article has been viewed

\author{
Shereen Elazzazy' \\ Asmaa Elhassan Mohamed ${ }^{2}$ \\ Amaal Gulied' \\ 'Pharmacy Department, ${ }^{2}$ Oncology \\ Hematology Department, National \\ Center for Cancer Care and \\ Research (NCCCR), Hamad Medical \\ Corporation, Doha, Qatar
}

\begin{abstract}
Cyclophosphamide is commonly used in the treatment of malignant diseases. Symptomatic severe hyponatremia induced by low-dose cyclophosphamide is very uncommon worldwide. We report a case of severe symptomatic hyponatremia that developed in a female breast cancer patient following the first cycle of chemotherapy containing low-dose cyclophosphamide. Her laboratory test showed serum $\mathrm{Na}$ of $112 \mathrm{mmol} / \mathrm{L}$. Her hyponatremia was initially treated with sodium bicarbonate. She completely recovered without neurological deficits after slow correction of the serum $\mathrm{Na}$ concentration. Although hyponatremia is a rare toxicity it should always be considered during the usage of cyclophosphamide, even if the dosage is low, especially with concurrent use of other medications that impair water excretion, like chlorthalidone. This report describes the first reported case of cyclophosphamide-induced hyponatremia in Qatar.
\end{abstract}

Keywords: AC protocol, adjuvant chemotherapy, breast cancer, cyclophosphamide, hyponatremia, thiazides

\section{Background}

Cyclophosphamide is an alkylating agent which was traditionally used to potentiate vasopressin renal action. Low doses of cyclophosphamide are being used in the treatment of rheumatological disorders, while higher doses are being used for treatment of malignant diseases. Although cyclophosphamide is extensively used in the management of different types of diseases, there have been only a few case reports of cyclophosphamide-induced hyponatremia.

Cyclophosphamide has common side effects such as bone marrow suppression, infection, sterility, alopecia, bladder malignancy, and hemorrhagic cystitis. ${ }^{1}$ However, a less generally known side effect is that intravenous (IV) cyclophosphamide could indirectly cause antidiuretic hormone release and reduce the ability of the kidney to excrete water. Since forced hydration is routinely used concomitantly with cyclophosphamide to prevent hemorrhagic cystitis, patients may retain water, developing severe hyponatremia rapidly. ${ }^{2}$ High doses $\left(>1,000 \mathrm{mg} / \mathrm{m}^{2}\right)$ of cyclophosphamide are being used in neoplastic diseases, when hyponatremia might be a major complication. ${ }^{3-6}$ Conversely, lower IV doses are being used with increasing frequency in the treatment of lymphoma, solid tumor, and systemic lupus, with only a few case reports of cyclophosphamide-induced hyponatremia reported. ${ }^{1,7,8}$

\section{Case presentation}

The patient, a 43 year old, premenopausal female with a history of hypertension, was diagnosed with early left breast cancer (T2 N0 M0 [II A according to American Joint

Phone +97455009621

Email shereen_amin@yahoo.com 
Committee on Cancer staging] $)^{9}$ in February 2013. She underwent left breast wire-guided wide local excision, with sentinel lymph node sampling, and axillary dissection. Histopathologic examination revealed invasive ductal carcinoma, grade 2 , hormone receptors were positive, and Her2/neu negative.

The patient was referred to the National Center for Cancer Care and Research (NCCCR). The plan of therapy was to receive four cycles of adjuvant chemotherapy (AC protocol) doxorubicin $\left(60 \mathrm{mg} / \mathrm{m}^{2}\right)$ and cyclophosphamide $\left(600 \mathrm{mg} / \mathrm{m}^{2}\right)$, followed by radiation therapy to the left breast, with hormonal therapy for 5 years.

Echocardiography was normal with left ventricular ejection fraction of $55 \%-60 \%$. On February 26, 2013, as the patient's operative wound had healed with good general performance and all laboratory values were normal (Table 1), she was started on chemotherapy (AC protocol) Cycle 1 with antiemetic protocol (aprepitant + dexamethasone + metoclopramide [if needed for nausea and vomiting]) as an outpatient in the NCCCR infusion unit, without immediate complications. Her home medications included only atenolol $(50 \mathrm{mg}) /$ chlorthalidone (12.5 mg) combined orally, once daily, for hypertension.

The patient developed severe nausea and vomiting on day 3 of chemotherapy. She presented to the urgent care department on day 3 with complains of generalized weakness, mental confusion, and generalized seizures. She collapsed in the accident and emergency area, was intubated, and then shifted to the medical intensive care unit. Laboratory tests showed serum $\mathrm{Na}$ of $112 \mathrm{mmol} / \mathrm{L}$; renal and liver functions (Table 1), arterial blood gases, procalcitonin, and computed tomography of the brain were all normal.

The patient was supplemented with electrolyte replacement and her serum Na level improved on March 11, 2013 to $129 \mathrm{mmol} / \mathrm{L}$. Her antihypertensive medication was held until resolution of hyponatremia was achieved. Blood cultures were negative, but her urine cultures grew Streptococcus agalactiae. She was extubated but then developed fever due to aspiration pneumonia. After treatment with IV antibiotics (piperacillin/tazobactam), the patient was transferred to NCCCR where her condition improved with correction of her serum $\mathrm{Na}$ level and antibiotics. Magnetic resonance imaging of the brain showed no metastasis. The patient was discharged on March 17, 2013 when her serum Na reached $138 \mathrm{mmol} / \mathrm{L}$.

It was decided that the rest of chemotherapy was to be given under direct supervision as an inpatient. She was admitted for the second cycle on March 28, 2013. On day 1 of Cycle 2; the patient's serum Na level was $142 \mathrm{mmol} / \mathrm{L}$ (prechemotherapy). On day 2, serum Na dropped to 127 $\mathrm{mmol} / \mathrm{L}$, and the patient was started on oral sodium chloride and IV sodium bicarbonate. Serum Na levels improved to

Table I Laboratory values on admission, before and after chemotherapy

\begin{tabular}{|c|c|c|c|c|c|c|c|c|}
\hline \multirow{2}{*}{$\begin{array}{l}\text { Cycle } \\
\text { Date of lab value }\end{array}$} & \multicolumn{2}{|c|}{$\begin{array}{l}\text { Cycle I dated } \\
07 / 03 / 2013\end{array}$} & \multicolumn{2}{|c|}{$\begin{array}{l}\text { Cycle } 2 \text { dated } \\
28 / 03 / 2013\end{array}$} & \multicolumn{2}{|c|}{$\begin{array}{l}\text { Cycle } 3 \text { dated } \\
29 / 04 / 2013\end{array}$} & \multicolumn{2}{|c|}{$\begin{array}{l}\text { Cycle } 4 \text { dated } \\
21 / 05 / 2013\end{array}$} \\
\hline & $06 / 03 / 13$ & $09 / 03 / 13$ & $24 / 03 / 13$ & $29 / 03 / 13$ & $29 / 04 / 13$ & $30 / 04 / 13$ & $21 / 05 / 13$ & $22 / 05 / 13$ \\
\hline Item & Before & After & $\overline{\text { Before }}$ & After & $\overline{\text { Before }}$ & After & $\overline{\text { Before }}$ & After \\
\hline Urine $\mathrm{Na} \mathrm{mmol} / \mathrm{L}$ & NA & NA & NA & 35 & NA & NA & NA & NA \\
\hline Blood glucose $\mathrm{mmol} / \mathrm{L}$ & 4.7 & 6.0 & 4.8 & 7.1 & 5.9 & 7.4 & 4.9 & 7.3 \\
\hline Serum creatinine umol/L & 54 & 50 & 60 & 36 & 50 & 47 & 51 & 55 \\
\hline Urea nitrogen $\mathrm{mmol} / \mathrm{L}$ & 4.3 & 5.1 & 4.3 & 4.0 & 2.3 & 3.1 & 3.6 & 4.0 \\
\hline $\mathrm{K} \mathrm{mmol} / \mathrm{L}$ & 4.2 & 3.5 & 4.2 & 3.8 & 3.5 & 3.1 & 4.5 & 3.6 \\
\hline $\mathrm{Na} \mathrm{mmol} / \mathrm{L}$ & 138 & 112 & 142 & 127 & 139 & 126 & 140 & $13 \mid$ \\
\hline $\mathrm{Cl} \mathrm{mmol} / \mathrm{L}$ & 99 & 74 & 99 & 91 & 99 & 87 & 4.5 & 91 \\
\hline $\mathrm{HCO}_{3} \mathrm{mmol} / \mathrm{L}$ & 25 & 20 & 25 & 20 & 27 & 19 & 25 & 22 \\
\hline $\mathrm{PO}_{4} \mathrm{mmol} / \mathrm{L}$ & 1.25 & 0.97 & 1.38 & 1.04 & 1.13 & 0.98 & 1.4 & 0.97 \\
\hline $\mathrm{Ca} \mathrm{mmol} / \mathrm{L}$ & 2.44 & 2.3 & 2.49 & 2.15 & 2.28 & 2.38 & 2.38 & 2.19 \\
\hline Corrected Ca mmol/L & 2.38 & 2.26 & 2.35 & 2.23 & 2.24 & 2.42 & 2.32 & 2.19 \\
\hline $\mathrm{Mg} \mathrm{mmol} / \mathrm{L}$ & 0.73 & 0.56 & 0.73 & 0.51 & 0.68 & 0.68 & 0.68 & 0.54 \\
\hline ALT U/L & 20 & 17 & 20 & NA & 24 & 21 & 47 & NA \\
\hline AST U/L & 18 & 16 & 16 & NA & 20 & 18 & 38 & NA \\
\hline T Bilirubin umol/L & 7 & 14 & 3 & NA & 5 & 6 & 4 & NA \\
\hline Albumin $g / L$ & 43 & 42 & 47 & 36 & 42 & 39 & 43 & 40 \\
\hline $\mathrm{WBC} \times 10^{3} / \mathrm{uL}$ & 8.9 & 12.6 & & & & & & \\
\hline ANC $\times 10^{3} / \mathrm{uL}$ & 5.0 & 10.0 & & & & & & \\
\hline $\mathrm{Hgb}$ g/dLa & 12.5 & 12.5 & & & & & & \\
\hline PLT $\times 10^{3} / \mathrm{uL}$ & 254 & 279 & & & & & & \\
\hline
\end{tabular}

Abbreviations: lab, laboratory; NA, not available; ALT, alanine transaminase; AST, aspartate aminotransferase; T, total; WBC, white blood cells; ANC, absolute neutrophil count; Hgb, hemoglobin; PLT, platelet count. 


\section{Cumulative summary report}

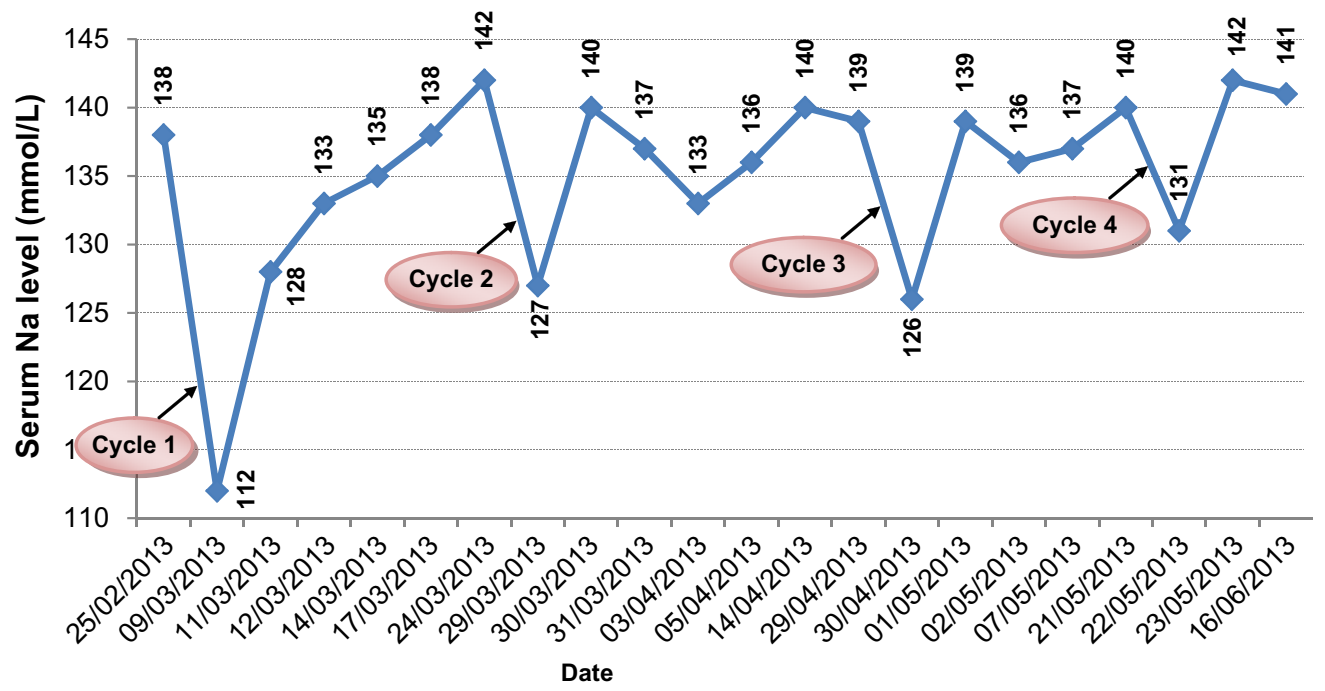

Figure I Cumulative summary report of serum $\mathrm{Na}$ level.

reach $140 \mathrm{mmol} / \mathrm{L}$ on March 30, 2013 (day 3), and she was discharged home on March 31, 2013 (Figure 1).

The patient was assessed in the outpatient clinic on April 5, 2013, where her serum Na was $136 \mathrm{mmol} / \mathrm{L}$, but she was suffering from severe fatigue, as well as nausea and vomiting. In an effort to decrease her distress, it was decided to consider a $25 \%$ dose reduction for Cycles 3 and 4 of chemotherapy (both chemotherapeutic agents). She was started on paroxetine (20 mg orally once daily) to relieve her anxiety.

On April 29, 2013 she was admitted for the third cycle of chemotherapy. On day 1 her serum Na was $139 \mathrm{mmol} / \mathrm{L}$ which dropped to $126 \mathrm{mmol} / \mathrm{L}$ on day 2 without major symptoms. As part of the management we tried to eliminate all factors that might contribute to hyponatremia, therefore chlorthalidone was withheld and the patient was prescribed atenolol in a higher dose (100 mg orally, once daily). The patient improved on IV and oral sodium bicarbonate, and she was discharged on May 1, 2013 (day 3) with a serum Na level of $139 \mathrm{mmol} / \mathrm{L}$. In Cycle 4, chlorthalidone was still on hold and the patient was kept on atenolol. Symptom-wise, she was much better after the dose reduction. The fourth cycle was given successfully on May 21, 2013, for which she was admitted for 3 days without severe drops in her serum Na level. She was started on a secondary prophylaxis of IV and oral sodium bicarbonate, and was kept on atenolol. Serum $\mathrm{Na}$ was $140 \mathrm{mmol} / \mathrm{L}$ before chemotherapy, $131 \mathrm{mmol} / \mathrm{L}$ on day 2 , and then $142 \mathrm{mmol} / \mathrm{L}$ on the day of discharge.

The patient was treated further with radiation therapy to the left breast in the period from June 11 to July 25, 2013 and started hormonal therapy with tamoxifen (20 mg per day orally) in June 2013.

\section{Discussion}

This report describes a breast cancer patient who developed severe hyponatremia after administration of the first and subsequent cycles of AC protocol. Cyclophosphamide is commonly used in the management of malignant diseases; severe cyclophosphamide-induced symptomatic hyponatremia is very uncommon, and there have been a limited number of case reports on cyclophosphamide-induced hyponatremia. The mechanisms of cyclophosphamide-induced hyponatremia have not been clearly understood, but cyclophosphamide could indirectly cause antidiuretic hormone release and reduce the ability of the kidney to excrete water.

The patient in our case was prescribed atenolol $(50 \mathrm{mg}) /$ chlorthalidone $(12.5 \mathrm{mg})$ for hypertension. Chlorthalidone is a thiazide diuretic. Thiazide diuretics are considered an essential first-line treatment of hypertension. ${ }^{11}$ Hyponatremia is an occasional but potentially fatal complication of thiazide diuretics. Thiazide diuretics inhibit

Table 2 Therapy management and relevant outcomes

\begin{tabular}{lllll}
\hline Item & Cycle I & Cycle 2 & Cycle 3 & Cycle 4 \\
\hline Dose modification & No & No & Yes & Yes \\
$\begin{array}{l}\text { Chlorthalidone Rx } \\
\text { Serum Na level } \\
\text { post-chemo (mmol/L) }\end{array}$ & Yes & Yes & Yes & No \\
$\begin{array}{l}\text { Discharge day } \\
\text { (day of cycle) }\end{array}$ & DII & D3 & D3 & D3 \\
LOS & 9 & 3 & 3 & 3 \\
\hline
\end{tabular}

Abbreviations: $\mathrm{Rx}$, prescription; chemo, chemotherapy; LOS, length of stay; D, day. 
Table 3 Naranjo Causality Scale for adverse drug reactions

\begin{tabular}{|c|c|c|c|c|}
\hline \multirow[t]{2}{*}{ Question } & \multicolumn{4}{|c|}{ Scoring } \\
\hline & Yes & No & $\begin{array}{l}\text { Do not know } \\
\text { or unavailable }\end{array}$ & Score \\
\hline I. Are there previous conclusive reports on this reaction? & +1 & 0 & 0 & +1 \\
\hline 2. Did the adverse event appear after the suspected drug was given? & +2 & +1 & 0 & +2 \\
\hline $\begin{array}{l}\text { 3. Did the adverse reaction improve when the drug was discontinued } \\
\text { or a specific antagonist was given? }\end{array}$ & +1 & 0 & 0 & +1 \\
\hline 4. Did the adverse reaction appear when the drug was readministered? & +2 & -1 & 0 & +2 \\
\hline 5. Are there alternative causes that could have caused the reaction? & -1 & +2 & 0 & +2 \\
\hline 6. Did the reaction reappear when a placebo was given? & -1 & +1 & 0 & 0 \\
\hline 7. Was the drug detected in any body fluid in toxic concentrations? & +1 & 0 & 0 & 0 \\
\hline $\begin{array}{l}\text { 8. Was the reaction more severe when the dose was increased/increasing, } \\
\text { or less severe when the dose was decreased? }\end{array}$ & +1 & 0 & 0 & +1 \\
\hline $\begin{array}{l}\text { 9. Did the patient have a similar reaction to the same or similar drugs } \\
\text { in any previous exposure? }\end{array}$ & +1 & 0 & 0 & 0 \\
\hline 10. Was the adverse event confirmed by any objective evidence? & +1 & 0 & 0 & +1 \\
\hline Total & & & & +10 \\
\hline
\end{tabular}

electrolyte transport in the diluting segment and may impair urinary dilution in some vulnerable groups. Thiazides act by inhibiting reabsorption of $\mathrm{Na}^{+}$and $\mathrm{Cl}^{-}$from the distal convoluted tubule by blocking the thiazide-sensitive $\mathrm{Na}^{+} / \mathrm{Cl}^{-}$ transporter. Risk factors predisposing to thiazide-induced hyponatremia include older age, female sex, reduced body mass, and concurrent use of other medications that impair water excretion. ${ }^{10}$

We noticed that when comparing Cycle 3 and Cycle 4; the symptoms of hyponatremia were better managed in Cycle 4 after withholding chlorthalidone. The serum $\mathrm{Na}$ level was corrected and patient discharged on day 5 of Cycle 3 and day 3 of Cycle 4 (Table 2). This is a novel finding in the sense that, to the authors' knowledge, hyponatremia induced by concomitant use of thiazides and cyclophosphamide has not been reported previously.

Using the Naranjo Causality Scale ${ }^{12}$ for adverse drug reactions, we obtained a score of $10(>9=$ definite adverse drug reaction; Table 3 ). Based on this and on the clinical and investigation findings, we considered a significant possibility of severe hyponatremia induced after the first and subsequent cycles of the AC protocol.

Further studies will be necessary to evaluate the likelihood of hyponatremia after low-dose IV cyclophosphamide therapy; the molecular mechanisms of hyponatremia induced by cyclophosphamide; risk factors for cyclophosphamideinduced hyponatremia; and establish dose dependent relationships of cyclophosphamide with the severity of hyponatremia and management of other concomitant agents expected to induce hyponatremia.

\section{Conclusion}

Because of the variety and the rarity of hyponatremia induced by low doses of cyclophosphamide, we emphasize the importance that physicians consider the probability of severe hyponatremia induced by low doses of cyclophosphamide, and evaluate all aspects of a patient's current medications during usage of cyclophosphamide. Furthermore, health care providers should be aware of this potential toxicity, appropriate monitoring should be implemented, and patients should be counseled to notify their physician if they develop any new or unusual symptoms.

\section{Disclosure}

The authors declare they have no conflicts of interest in this work.

\section{References}

1. Webberley MJ, Murray JA. Life-threatening acute hyponatremia induced by low-dose cyclophosphamide and indomethacin. Postgrad Med J. 1989;65:950-952.

2. Spital A, Ristow S. Cyclophosphamide induced water intoxication in a woman with Sjögren's syndrome. J Rheumatol. 1997;24: 2473-2475.

3. DeFronzo RA, Braine H, Colvin OM, Davis PJ. Water intoxication in man after cyclophosphamide therapy. Time course and relation to drug activation. Ann Intern Med. 1973;78:861-869.

4. Steele TH, Serpick AA, Block JG. Antidiuretic response to cyclophosphamide in man. J Pharmacol Exp Ther. 1973;185:245-253.

5. DeFronzo RA, Colvin OM, Braine H, Roberson GL, Davis PJ. Cyclophosphamide and the kidney. Cancer. 1974;33:483-491.

6. Harlow PJ, DeClerck YA, Shore NA, Ortega JA, Carranza A, Heuser E. A fatal case of inappropriate ADH secretion induced by cyclophosphamide therapy. Cancer. 1979;44:896-898.

7. McCarron M, Wright GD, Roberts SD. Water intoxication after low dose cyclophosphamide. BMJ. 1995;311:292. 
8. Salido M, Macarron P, Hernández-García C, D’Cruz DP, Khamashta MA, Hughes GR. Water intoxication induced by low-dose cyclophosphamide in two patients with systemic lupus erythematosus. Lupus. 2003;12: 636-639.

9. Edge SB, Byrd DR, Compton CC, Fritz AG, Greene FL, Trotti A, editors. AJCC Cancer Staging Manual. 7th edition. New York: Springer; 2010.

10. Suzanne H, Anthony S. First-line medicines in the treatment of hypertension. Aust Prescr. 2005;28:34-37.
11. Green TP, Mirkin BL. Prevention of cyclophosphamide-induced antidiuresis by furosemide infusion. Clin Pharmacol Ther. 1981;29:634-642.

12. Naranjo CA, Busto U, Sellers EM, et al. A method for estimating the probability of adverse drug reactions. Clin Pharmacol Ther. 1981;30: 239-245.

\section{Publish your work in this journal}

OncoTargets and Therapy is an international, peer-reviewed, open access journal focusing on the pathological basis of all cancers, potential targets for therapy and treatment protocols employed to improve the management of cancer patients. The journal also focuses on the impact of management programs and new therapeutic agents and protocols on

\section{Dovepress}

patient perspectives such as quality of life, adherence and satisfaction. The manuscript management system is completely online and includes a very quick and fair peer-review system, which is all easy to use. Visit http://www.dovepress.com/testimonials.php to read real quotes from published authors.

Submit your manuscript here: http://www.dovepress.com/oncotargets-and-therapy-journal 